Article

\title{
Activity and stability of bacterial cellulase immobilized on magnetic nanoparticles
}

\author{
Kandasamy Selvam a,t, Muthusamy Govarthanan b,c,t, Duraisamy Senbagam d, \\ Seralathan Kamala-Kannan e, Balakrishnan Senthilkumar a,f, , Thangasamy Selvankumar b,\# \\ a Centre for Biotechnology, Muthayammal College of Arts and Science, Rasipuram, Namakkal 637408, Tamil Nadu, India \\ b PG and Research Department of Biotechnology, Mahendra Arts and Science College (Autonomous), Kalippatti, Namakkal 637501, Tamil Nadu, India \\ c Department of Applied Sciences, College of Environmental Technology, Muroran Institute of Technology, 27-1 Mizumoto, Muroran, Hokkaido 050-8585, \\ Japan \\ d Department of Marine Biotechnology, Bharathidasan University, Tiruchirappalli 620024, Tamil Nadu, India \\ e Division of Biotechnology, Advanced Institute of Environment and Bioscience, College of Environmental and Bioresource Sciences, Chonbuk National \\ University, Iksan 570752, South Korea \\ ${ }^{\mathrm{f}}$ Department of Medical Microbiology, College of Health and Medical Sciences, Haramaya University, P.0. Box 235, Harar, Ethiopia
}

\section{A R T I C L E I N F O}

\section{Article history:}

Received 8 May 2016

Accepted 14 June 2016

Published 5 November 2016

\section{Keywords:}

Magnetic nanoparticle

Immobilized enzyme

Response surface methodology

Characterization

\begin{abstract}
A B S T R A C T
Magnetic nanoparticles $\left(\mathrm{Fe}_{3} \mathrm{O}_{4}\right)$ were synthesized by co-precipitating $\mathrm{Fe}^{2+}$ and $\mathrm{Fe}^{3+}$ ions in an ammonia solution and treating under hydrothermal conditions. Cellulase was immobilized onto $\mathrm{Fe}_{3} \mathrm{O}_{4}$ magnetic nanoparticles via glutaraldehyde activation. Using response surface methodology and Box-Behnken design, the variables such as magnetic nanoparticle concentration, glutaraldehyde concentration, enzyme concentration, and cross linking time were optimized. The Box-Behnken design analysis showed a reasonable adjustment of the quadratic model with the experimental data. Statistical contour plots were generated to evaluate the changes in the response surface and to understand the relationship between the nanoparticles and the enzyme activity. Scanning electron microscopy, X-ray diffraction analysis, and Fourier transform infrared spectroscopy were studied to characterize size, structure, morphology, and binding of enzyme onto the nanoparticles. The stability and activity of the bound cellulase was analyzed using various parameters including $\mathrm{pH}$, temperature, reusability, and storage stability. The immobilized cellulase was compared with free cellulase and it shows enhanced stability and activity.
\end{abstract}

(C) 2016, Dalian Institute of Chemical Physics, Chinese Academy of Sciences. Published by Elsevier B.V. All rights reserved.

\section{Introduction}

Enzymes are used as biocatalysts in chemical, pharmaceutical, and food industries [1,2]. Because the recovery and the reusability of free enzyme reactions are limited [3], attention has been paid to enzyme immobilization, which offers advantages over free enzymes, such as the possibility of continu- ous process, rapid termination of reactions, controlled product formation, ease of enzyme removal from the reaction mixture, and adaptability to various engineering designs [4].

The immobilization of biomolecules onto insoluble supports is an important tool to fabricate a diverse range of functional materials or devices [5]. It provides many distinct advantages including enhanced stability, easy separation from reaction

\footnotetext{
* Corresponding author. E-mail: nbsenthilkumar@gmail.com

\# Corresponding author. Tel: +91-9443286292,+91-9443470394; E-mail: t_selvankumar@yahoo.com

† These authors contributed equally to this work.
}

DOI: 10.1016/S1872-2067(16)62487-7 | http://www.sciencedirect.com/science/journal/18722067 | Chin. J. Catal., Vol. 37, No. 11, November 2016 
mixture, possible modulation of the catalytic properties, and easier prevention of microbial growth [6]. Using magnetic supports for immobilization is promising. Magnetic carrier particles fulfill two functions of a magnetic material that allows ensembles to form with the species to be separated and surface properties that enable a selective separation.

The immobilization of enzymes onto nanomaterials such as nanopolymers [7], nanofiber [8], and nanoparticles [9,10] is of high interest because the reduction in the size of the enzyme carrier materials improves the efficiency of immobilized enzymes. Moreover, for surface attachment, smaller particles can provide a larger surface area for the attachment of enzymes, leading to higher enzyme loading per unit mass of particles [9]. However, for industrial biotechnology applications, immobilized enzymes on nanoparticles are limited by problems in recovery, e.g., via centrifugation or filtration.

Magnetic nanoparticles (MNPs) are potentially useful supports for bioactive materials such as peptides, enzymes, antibodies, and nucleic acids, and are easily recovered for reuse [11-15]. They have low toxicity, and their distinct advantage is their separation from reaction mixtures using magnets. Improved enzyme activity, loading, and stability using enzyme immobilized on MNPs have been shown by Dyal et al. [16].

Many chemical procedures used to synthesize magnetic nanoparticles and microparticles are applicable for bioapplications, such as classical co-precipitation, reactions in constrained environments (e.g., microemulsions), sol-gel syntheses, sonochemical and microwave reactions, hydrothermal reactions, hydrolysis and thermolysis of precursors, flow injection syntheses, electrospray syntheses, and mechanochemical processes [17-19].

Cellulase (1,4-(1,3;1,4)-D-glucan 4-glucanohydrolase, EC 3.2.1.4) can be used as a biocatalyst for cellulose hydrolysis. The cost of cellulase technology can be reduced by increasing the enzyme reusability and its stability. These may be accomplished by enzyme immobilization on suitable carriers. The immobilization of cellulase enzyme complex on magnetic supports has also reported [20]. The purpose of this study was to characterize the cellulase complex after direct binding to magnetic nanoparticles via glutaraldehyde cross linking and determine optimum operating conditions. Size and structure of the resultant nanoparticles were characterized by scanning electron microscopy (SEM). Binding of magnetite nanoparticles to enzyme was confirmed using Fourier transform infrared (FTIR) spectroscopy and X-ray diffraction (XRD). Operating parameters for immobilized cellulase were evaluated using varying $\mathrm{pH}$ and thermal conditions, in addition to the binding efficiency of enzyme to the support, to determine the conditions for optimum hydrolysis reactions.

\section{Experimental}

\subsection{Materials}

Cellulase (from Acinetobacter sp. TSK-MASC) [21], Glutaraldehyde (25 wt $\%$ solution in water), $\mathrm{FeCl}_{3} \cdot 6 \mathrm{H}_{2} \mathrm{O}, \mathrm{FeCl}_{2} \cdot 4 \mathrm{H}_{2} \mathrm{O}$ carboxymethyl cellulose (CMC), 3,5-dinitrosalicylic acid, Folin's reagent $(2 \mathrm{~N})$, and sodium phosphate were purchased from Hi-media, Mumbai, India. All other chemicals were obtained from local suppliers and were analytical grade or better.

\subsection{Preparation of magnetic nanoparticles}

Magnetic nanoparticles $\left(\mathrm{Fe}_{3} \mathrm{O}_{4}\right)$ were prepared by co-precipitating $\mathrm{Fe}^{2+}$ and $\mathrm{Fe}^{3+}$ ions with ammonia solution and treating under hydrothermal conditions as previously reported, but with minor modifications [13,22]. A 2:1 molar ratio of ferric and ferrous chlorides was dissolved in water under inert conditions. Chemical precipitation was achieved at $25{ }^{\circ} \mathrm{C}$ under vigorous stirring by adding $28 \% \mathrm{NH}_{4} \mathrm{OH}$ solution. The precipitates were heated to $80{ }^{\circ} \mathrm{C}$ for $30 \mathrm{~min}$, and washed three times with water and once with anhydrous ethanol. The particles were dried for $24 \mathrm{~h}$.

\subsection{Immobilization of cellulase on magnetic nanoparticles}

The immobilization of cellulase on magnetic nanoparticles followed the procedure described by Verma et al. [23] with minor modifications. The magnetic nanoparticles were suspended in deionized water at a concentration of $5 \mathrm{mg} / \mathrm{mL}$. This suspension was sonicated for $1 \mathrm{~h}$, and suspended in $1 \mathrm{~mol} / \mathrm{L}$ glutaraldehyde solution in deionized water [23]. The support was activated by incubating the magnetic nanoparticles for $1 \mathrm{~h}$ at $25{ }^{\circ} \mathrm{C}$ in a shaker at $250 \mathrm{r} / \mathrm{min}$. The reaction mixture was stored at $4{ }^{\circ} \mathrm{C}$ and sonicated at 1-h intervals to ensure uniform dispersion. After $2 \mathrm{~h}$, the mixture was sonicated a final time and heated to $25{ }^{\circ} \mathrm{C}$. The cellulase-bound nanoparticles were recovered by placing the container on a strong permanent magnet. They were washed twice in water and the resultant supernatants were used for protein analysis. The remaining precipitates were analyzed for enzymatic activity and stability.

\subsection{Determination of enzyme activity}

The cellulase activity was measured using CMC, and the amount of released glucose equivalent during the hydrolysis of CMC solution [24]. A 1\% (w/v) CMC solution in acetate buffer pH 5 was used as the substrate. First, $1 \mathrm{~mL}$ of substrate solution and $1 \mathrm{~mL}$ of the immobilized enzyme were incubated at $37{ }^{\circ} \mathrm{C}$ for $1 \mathrm{~h}$. The reaction was stopped by putting the enzyme reaction tubes in a boiling water bath for $15 \mathrm{~min}$. The amount of reducing sugar was measured using the 3,5-dinitrosalicylic acid method [25]. One unit of enzyme activity is defined as the amount of enzyme producing $1 \mathrm{~mol} / \mathrm{L}$ of glucose equivalent per min at $37{ }^{\circ} \mathrm{C}$ and $\mathrm{pH} 5$. All experiments were conducted in triplicate, and reported as mean \pm standard deviation.

\subsection{Statistical optimization of immobilization process}

Response surface methodology combined with Box-Behnken design (BBD) was established using Design Expert software (9-0.0.7 trial version). Four factors, enzyme concentration, magnetic nanoparticle concentration, cross linking (glutaraldehyde \%), and cross linking time were optimized for 
immobilization. Using BBD, the factors were analyzed at two levels: -1 for the low level and +1 for the high level. A total of 29 runs were performed to optimize the process parameters, and experiments were performed in accordance with the experimental design matrix. The results were assessed by applying the coefficient of determination $\left(R^{2}\right)$, analysis of variance, and response plots. Response surface methodology was employed with the most widely used second-order polynomial equation developed to fit the experimental results and identify the relevant model terms

$$
Y=\beta_{0} \Sigma \beta_{i} \mathrm{X}_{i}+\Sigma \beta_{i} \mathrm{X}_{i} \beta_{i j}+\Sigma \mathrm{X}_{i} \mathrm{X}_{j}
$$

where $Y$ is the predicted response, $\beta_{0}, \beta_{i}$, and $\beta_{i j}$ are constant regression coefficients of the model, and $X_{i}$ and $X_{j}$ represent independent variables.

\subsection{Characterization methods}

SEM (Jeol JSM 6390 model) was performed to study the surface morphology of magnetic nanoparticles before and after cross linking of cellulase. Samples were dehydrated and mounted on stubs and sputter coated with gold for $300 \mathrm{~s}$ in a high vacuum and analyzed at a voltage acceleration of $10 \mathrm{kV}$.

The binding of cellulase onto MNPs was analyzed by FTIR spectrometer (Shimadzu). The samples were obtained by direct transmittance using the $\mathrm{KBr}$ pellet technique. The spectra of $400-4000 \mathrm{~cm}^{-1}$ were analyzed at a spectra resolution of $1 \mathrm{~cm}^{-1}$.

Table 1

Box-Behnken design for the variables and the experimental observed responses.

\begin{tabular}{|c|c|c|c|c|c|}
\hline Run & $\begin{array}{c}\text { Enzyme } \\
\text { conc. } \\
(\mathrm{mg} / \mathrm{mL})\end{array}$ & $\begin{array}{c}\text { MNPs } \\
\text { conc. } \\
(\mathrm{mg} / \mathrm{mL})\end{array}$ & $\begin{array}{c}\text { Cross linking } \\
\text { (glutraldehyde) } \\
(\%)\end{array}$ & $\begin{array}{c}\text { Time course } \\
\text { of cross } \\
\text { linking }(\mathrm{h}) \\
\end{array}$ & $\begin{array}{c}\text { Enzyme } \\
\text { activity } \\
(\%)\end{array}$ \\
\hline 1 & 0.025 & 300 & 0.3 & 1 & 50 \\
\hline 2 & 0.025 & 500 & 0.3 & 3 & 70 \\
\hline 3 & 0.1 & 500 & 0.3 & 3 & 48 \\
\hline 4 & 0.0625 & 300 & 0.5 & 5 & 87 \\
\hline 5 & 0.0625 & 300 & 0.3 & 3 & 85 \\
\hline 6 & 0.0625 & 300 & 0.3 & 3 & 87 \\
\hline 7 & 0.1 & 300 & 0.1 & 3 & 71 \\
\hline 8 & 0.0625 & 300 & 0.1 & 5 & 92 \\
\hline 9 & 0.1 & 300 & 0.3 & 1 & 92 \\
\hline 10 & 0.0625 & 300 & 0.1 & 1 & 79 \\
\hline 11 & 0.0625 & 100 & 0.5 & 3 & 52 \\
\hline 12 & 0.0625 & 300 & 0.5 & 1 & 80 \\
\hline 13 & 0.0625 & 500 & 0.3 & 5 & 82 \\
\hline 14 & 0.1 & 300 & 0.5 & 3 & 80 \\
\hline 15 & 0.0625 & 500 & 0.5 & 3 & 51 \\
\hline 16 & 0.0625 & 300 & 0.3 & 3 & 87 \\
\hline 17 & 0.025 & 300 & 0.1 & 3 & 47 \\
\hline 18 & 0.025 & 300 & 0.5 & 3 & 91 \\
\hline 19 & 0.0625 & 500 & 0.1 & 3 & 73 \\
\hline 20 & 0.025 & 100 & 0.3 & 3 & 78 \\
\hline 21 & 0.0625 & 100 & 0.1 & 3 & 85 \\
\hline 22 & 0.0625 & 100 & 0.3 & 5 & 83 \\
\hline 23 & 0.0625 & 300 & 0.3 & 3 & 54 \\
\hline 24 & 0.025 & 300 & 0.3 & 5 & 72 \\
\hline 25 & 0.0625 & 500 & 0.3 & 1 & 70 \\
\hline 26 & 0.0625 & 100 & 0.3 & 1 & 72 \\
\hline 27 & 0.0625 & 300 & 0.3 & 3 & 91 \\
\hline 28 & 0.1 & 300 & 0.3 & 5 & 92 \\
\hline 29 & 0.1 & 100 & 0.3 & 3 & 75 \\
\hline
\end{tabular}

The crystalline structure of the MNPs was characterized using X-ray diffractometer (XRD6000, Shimadzu) measurements performed at $40 \mathrm{kV}$ and $30 \mathrm{~mA}$. The $\theta-2 \theta$ method was applied to collect the diffraction spectra.

\subsection{Effects of $\mathrm{pH}$, temperature, storage stability, and reusability on the immobilized enzyme}

The effect of $\mathrm{pH}$ on free and immobilized cellulase activity was analyzed by measuring the reaction at different $\mathrm{pH}$ levels (5-11). The effects of incubation temperature on free and immobilized cellulase activities were determined by performing the reaction at $40-80^{\circ} \mathrm{C}$. The stabilities of free and immobilized cellulase was determined after storage in phosphate buffer $(0.02 \mathrm{~mol} / \mathrm{L}, \mathrm{pH} 7.0)$ at $4{ }^{\circ} \mathrm{C}$ for $100 \mathrm{~d}$. Retained activities were measured as described above, and the activity of each preparation was expressed as a percentage of its retained activity compared with its initial activity. To evaluate the reusability of the immobilized cellulase, the matrices were washed with water and buffer after use and suspended again in a fresh reaction mixture to measure the enzymatic activity.

\section{Results and discussion}

\subsection{Optimization of the immobilization parameters}

Magnetic nanoparticles were prepared by the co-precipitation method. The cellulase was immobilized onto $\mathrm{Fe}_{3} \mathrm{O}_{4}$ magnetic nanoparticles using glutaraldehyde as the cross linking agent. BBD was implemented to identify the optimal conditions for cellulase immobilization. The experimental design is shown in Table 1. Analysis of variance of the quadratic regression model (Table 2) exhibits that it was a highly significant model

\section{Table 2}

Analysis of variance (ANOVA) for the response surface quadratic model.

\begin{tabular}{lrrrrc}
\hline Source $^{\text {a }}$ & $\begin{array}{r}\text { Sum of } \\
\text { squares }\end{array}$ & df & $\begin{array}{c}\text { Mean } \\
\text { square }\end{array}$ & $F$ value & $\begin{array}{c}p \text {-value } \\
\text { Prob }>F\end{array}$ \\
\hline Model & 5592.85 & 14 & 399.49 & 14.79 & $<0.0001$ b \\
$\mathrm{A}$ & 2914.08 & 1 & 2914.08 & 107.90 & $<0.0001$ \\
$\mathrm{~B}$ & 48.00 & 1 & 48.00 & 1.78 & 0.2038 \\
$\mathrm{C}$ & 3.00 & 1 & 3.00 & 0.11 & 0.7439 \\
$\mathrm{D}$ & 44.08 & 1 & 44.08 & 1.63 & 0.2222 \\
$\mathrm{AB}$ & 12.25 & 1 & 12.25 & 0.45 & 0.5116 \\
$\mathrm{AC}$ & 1.00 & 1 & 1.00 & 0.037 & 0.8502 \\
$\mathrm{AD}$ & 36.00 & 1 & 36.00 & 1.33 & 0.2676 \\
$\mathrm{BC}$ & 4.00 & 1 & 4.00 & 0.15 & 0.7061 \\
$\mathrm{BD}$ & 6.25 & 1 & 6.25 & 0.23 & 0.6379 \\
$\mathrm{CD}$ & 49.00 & 1 & 49.00 & 1.81 & 0.1994 \\
$\mathrm{~A}^{2}$ & 2222.00 & 1 & 2222.00 & 82.27 & $<0.0001$ \\
$\mathrm{~B}^{2}$ & 264.30 & 1 & 264.30 & 9.79 & 0.0074 \\
$\mathrm{C} 2$ & 541.09 & 1 & 541.09 & 20.03 & 0.0005 \\
$\mathrm{D}^{2}$ & 234.16 & 1 & 234.16 & 8.67 & 0.0107 \\
Residual & 378.12 & 14 & 27.01 & - & - \\
Lack of fit & 376.92 & 10 & 37.69 & 125.64 & $<0.0001 \mathrm{~b}$ \\
Pure error & 1.20 & 4 & 0.30 & - & - \\
Cor total & 5970.97 & 28 & - & - & - \\
\hline a A: Enzyme concentration; B: MNPs concentration; C: & Cross linking \\
(glutraldehyde); D: Time course of cross linking. & \\
bSignificant. & \multicolumn{5}{|c}{}
\end{tabular}


as was evident from the Fisher's $F$-test with a very low probability value $(F$-value $=6.33)$. Values of 'Probability $>F(0.0007)$ indicate that the term of the model was significant. The Model $F$-value of 6.33 implies that the model was significant. There was only a $0.01 \%$ chance that a model $F$-value could occur because of noise. The predicted $R^{2}(0.2219)$ and adjusted $R^{2}$ (0.7271) values for optimal conditions were in reasonable

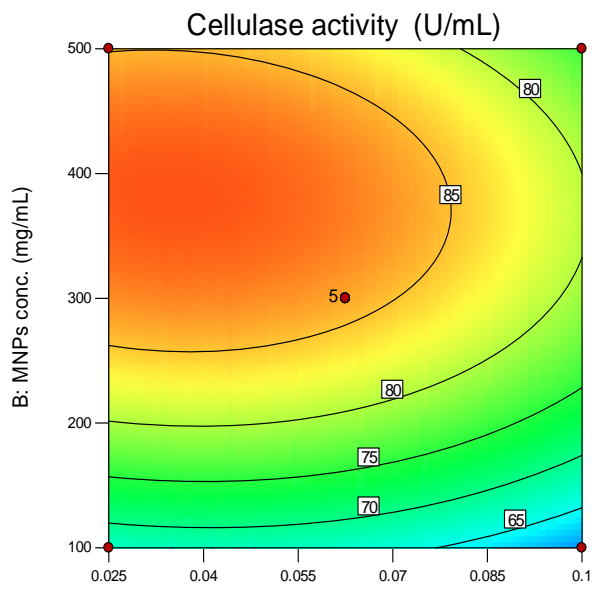

A: Enzyme conc. $(\mathrm{mg} / \mathrm{mL})$
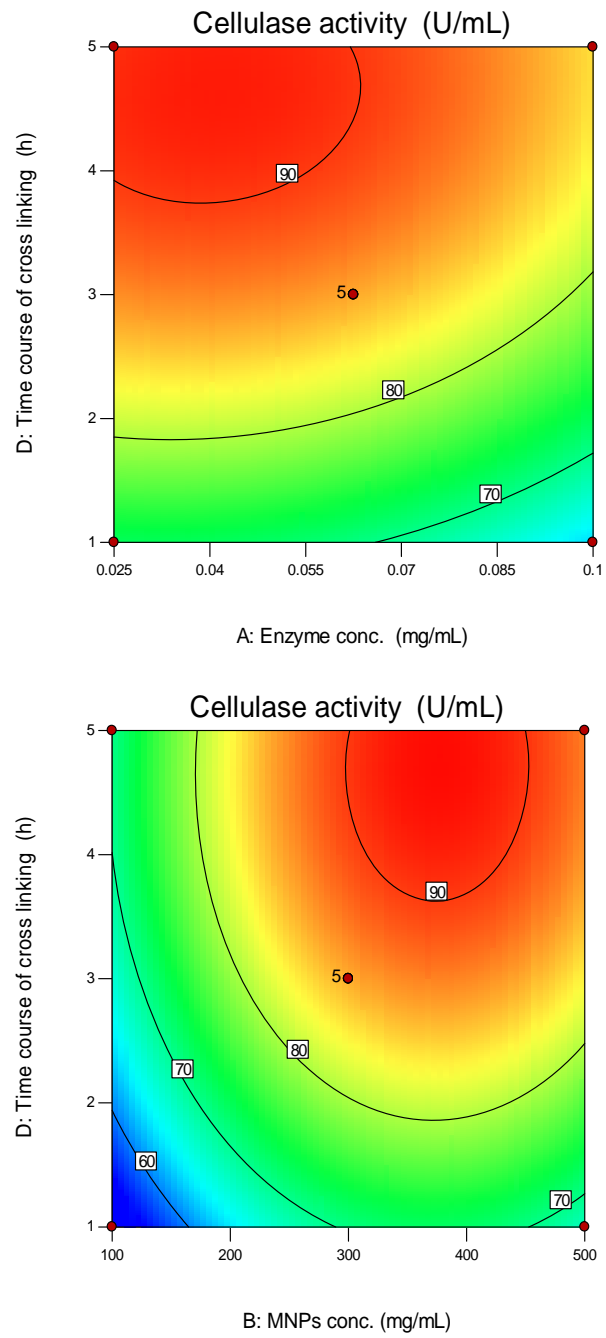

agreement with the value of $R^{2}(0.8636)$, which is closer to 1.0 , indicating the better fit of the model in the experimental data. The model for optimal conditions for cellulase immobilization, three different tests, sequential model sum of squares, lack of fit tests, and model summary statistics were performed.

Contour plots graphical representations were generated (Fig. 1). The results demonstrate that there was a significant

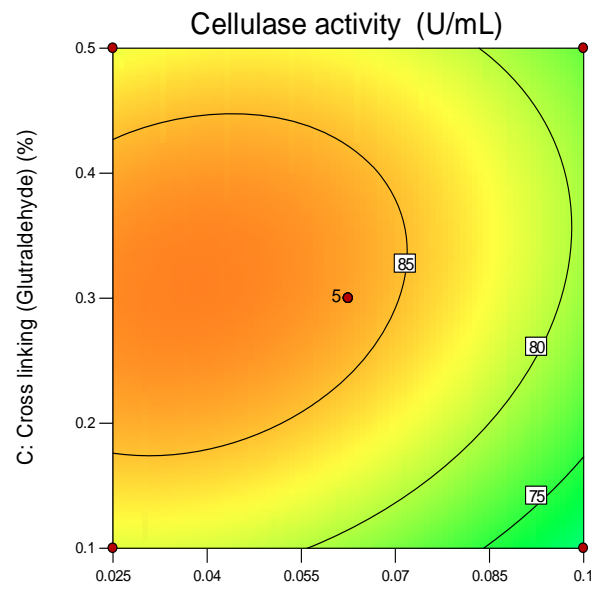

A: Enzyme conc. ( $\mathrm{mg} / \mathrm{mL})$
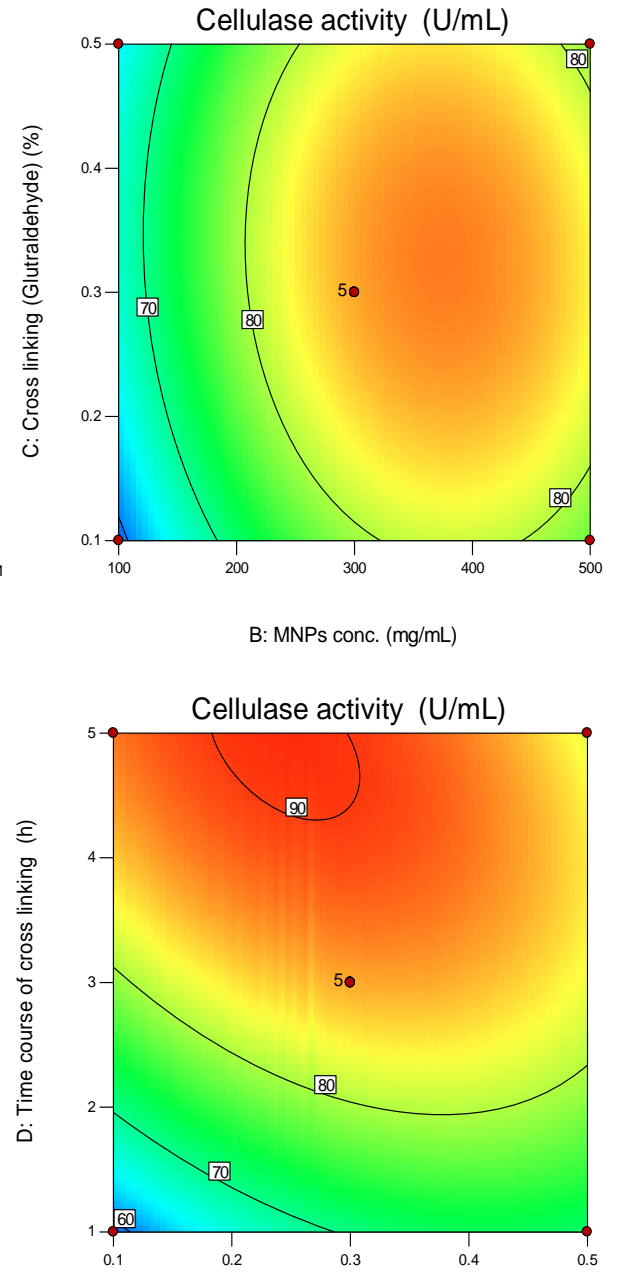

C: Cross linking (Glutraldehyde) (\%)

Fig. 1. Contour plots of the combined effects of two variables on cellulase immobilization. 
relationship among enzyme concentration, magnetic nanoparticle concentration, cross linking (glutaraldehyde \%), and crosslinking time. The optimum levels of the variables were obtained using BBD. The model predicted a maximum cellulase activity recovery of $92 \%$ for an enzyme concentration of $0.0625 \mathrm{mg} / \mathrm{mL}$, magnetic nanoparticle concentration of 300 $\mathrm{mg} / \mathrm{mL}$, cross linking with glutaraldehyde at $0.3 \%$, and a cross linking time of $3 \mathrm{~h}$. The predicted model was validated and experiments were conducted using these optimal conditions. The predicted model values were in good agreement with the values measured in these experiments, mitigating the validity of the response model and the necessity for optimal conditions. Graphs highlighted the parts played by the variables for the production of cellulase. The coefficients of the regression equation were calculated, and the following regression equation was achieved:

$$
\begin{gathered}
Y=+90.80-2.08 A+0.67 B+4.00 C+1.25 D+3.75 A B+ \\
1.00 A C+0.50 A D+1.25 B C-1.00 B D+3.25 C D- \\
9.57 A^{2}-7.44 B^{2}-4.19 C^{2}-6.82 D^{2}
\end{gathered}
$$

where $Y$ is cellulase activity, $A$ is enzyme concentration, $B$ is magnetic nanoparticle concentration, $C$ is cross linking (glutaraldehyde $\%$ ), and $D$ is cross linking time. A high degree of similarity of experimental values were observed, reflecting the precision and applicability of response surface methodology to optimize the enzyme immobilization.

\subsection{Characterization studies}

SEM was used to study the surface morphology of MNPs with and without bonded cellulase. The surface morphology of MNPs was changed after cellulase immobilization. These changes can easily be distinguished in the SEM (Fig. 2). The micrographs showed the surface of MNPs before immobilization of enzyme and after immobilization. There was a slight aggregation of enzyme particles present on the MNP surface.

The crystal structures of the composite magnetic nanoparticles were characterized by XRD and are shown in Fig. 3. For the $\mathrm{Fe}_{3} \mathrm{O}_{4}$ MNPs before immobilization, six characteristic peaks $(2 \theta$ $=30.08^{\circ}, 35.42^{\circ}, 43.08^{\circ}, 53.56^{\circ}, 56.98^{\circ}$, and $\left.62.62^{\circ}\right)$ marked by their indices ((220), (311), (400), (422), (511), and (440), respectively) were observed [26].

The binding of cellulase onto activated nanoparticles was confirmed by FTIR spectroscopy. Fig. 4 represents the FTIR spectra of activated nanoparticles, cellulase-bound nanoparticles, and cellulase. FTIR bands at $500-700 \mathrm{~cm}^{-1}$ were the vibra-

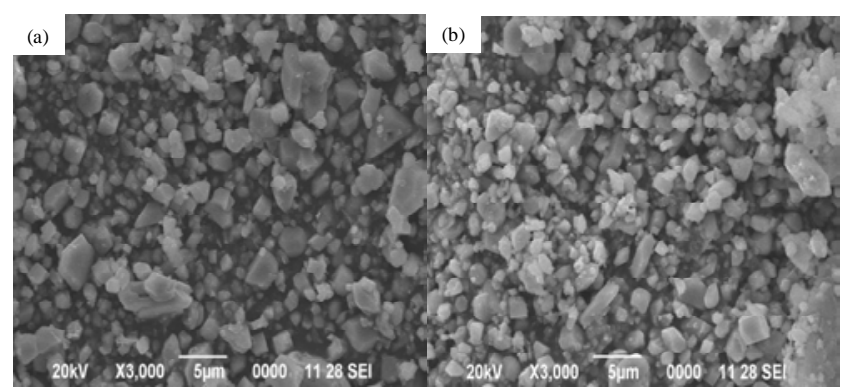

Fig. 2. SEM images of MNPs with (a) and without (b) bonded cellulase.

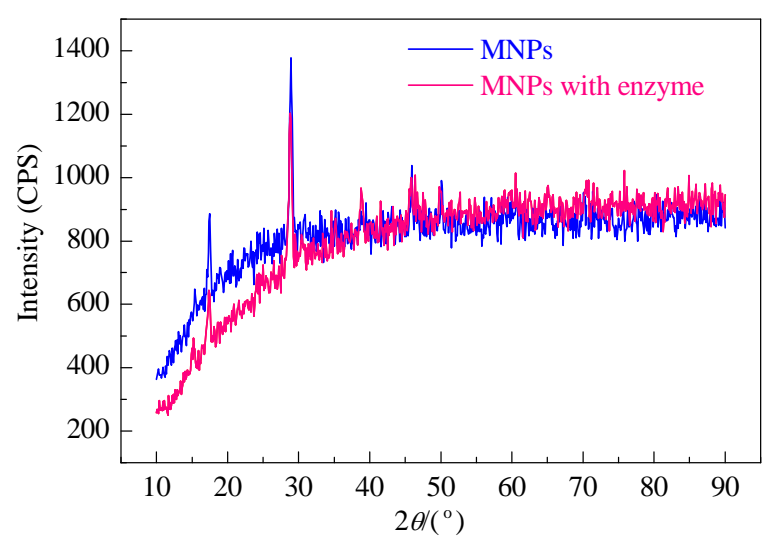

Fig. 3. XRD patterns of magnetic nanoparticles and immobilized magnetic particles.

tions of Fe-O bonds of iron oxide (Moon et al., 2000). The characteristic absorption peak of $\mathrm{Fe}_{3} \mathrm{O}_{4}$ is at $563.75 \mathrm{~cm}^{-1}$ [27]. After immobilization, new absorption bands at 1512.56 and $3180.92 \mathrm{~cm}^{-1}$ appeared, which are the $\mathrm{NH}_{4}{ }^{+}$bending vibration and $\mathrm{N}-\mathrm{H}$ bond, respectively, in the enzyme structure and confirm enzyme immobilization.

\subsection{Effect of $p H$ and temperature on enzyme activity and stability}

The effect of $\mathrm{pH}$ on the activity of free and immobilized cellulase was examined (Fig. 5(a)). The immobilized enzyme showed increasing activity at higher $\mathrm{pH}$ values compared with that of the free enzyme. The binding between cellulase and the amino bonds on nanoparticles improves resistance to a medium with high alkalinity. The alkaline medium affected the free enzyme by placing the enzyme in an electrostatic state that reduced activity. The binding onto MNPs allows the enzyme to retain the conformation and structural arrangement for activity and stability.

The effect of temperature on the activity of free and immobilized cellulase was examined (Fig. 5(b)). The optimum temperature for the free cellulase was observed at $50{ }^{\circ} \mathrm{C}$, whereas the maximum activity of both immobilized cellulase prepara-

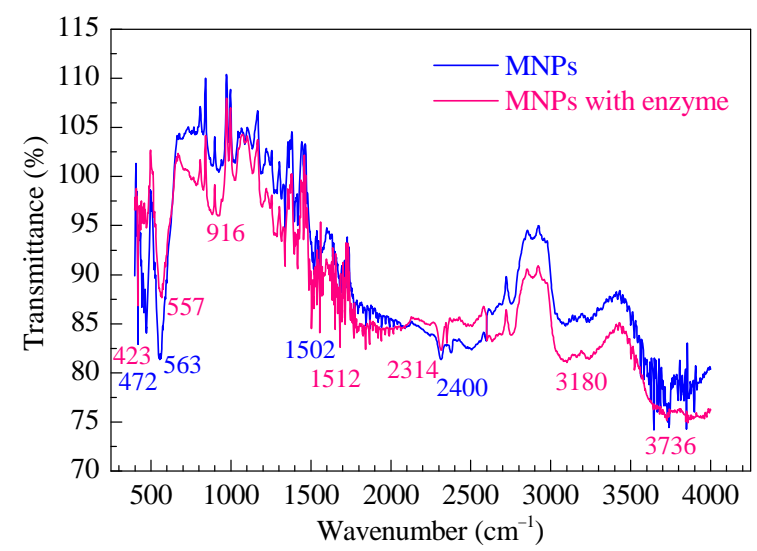

Fig. 4. FTIR spectra of magnetic nanoparticles and immobilized magnetic particles recorded in $\mathrm{KBr}$ pellets. 

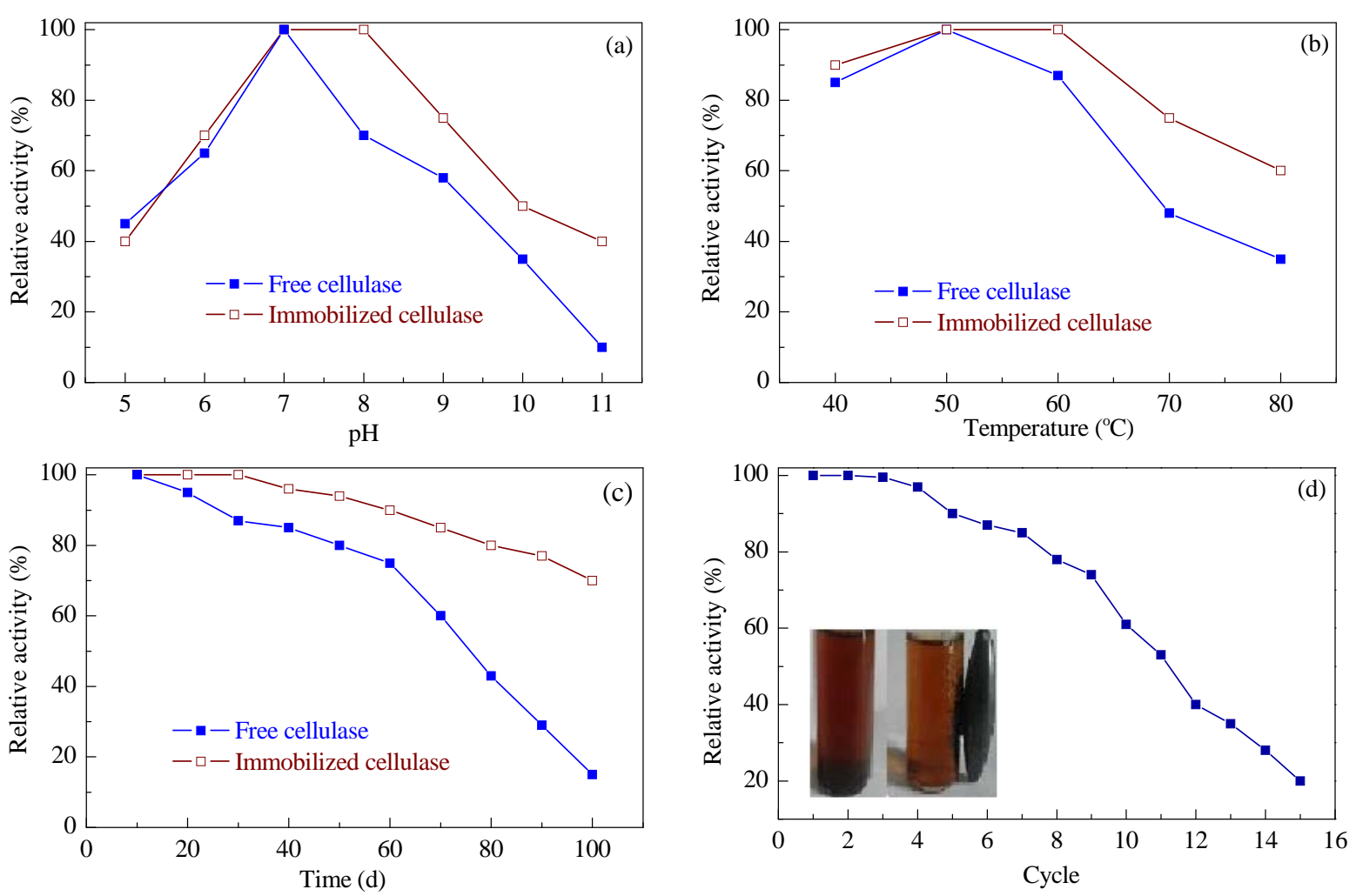

Fig. 5. (a) Effect of pH on the immobilized and free cellulase at different $\mathrm{pH}$; (b) The comparison of immobilized and free cellulase at various temperatures; (c) The storage stabilities of immobilized and free cellulose; (d) Reusability study of immobilized enzyme using CMC substrate.

tions showed an optimum temperature at $55^{\circ} \mathrm{C}$. However, both immobilized cellulase preparations showed higher activities over a wider range of temperatures than those of the free enzyme. The increase in optimum temperature for the immobilized cellulase preparation may be caused by the changing physical and chemical properties of the enzyme. An earlier study conducted on immobilization using cellulase binding to magnetic nanoparticle supports showed an optimum activity at $50{ }^{\circ} \mathrm{C}[28]$ and most of the immobilized cellulase exhibited higher optimum temperature values than their free counterpart [29,30].

\subsection{Storage stability}

The storage stabilities at $4{ }^{\circ} \mathrm{C}$ in the dry state were investigated by measuring the enzyme activities at certain time intervals $(0-100 \mathrm{~d})$, and the results are given in Fig. 5(c). The enzyme activity was determined at $37{ }^{\circ} \mathrm{C}$ in phosphate buffer $\mathrm{pH}$ 7. The free cellulase maintained $15 \%$ from its original activity, and the immobilized cellulase on MNPs maintained $70 \%$ from its initial activity after $100 \mathrm{~d}$. High storage stabilities have been reported for immobilized enzymes with a magnetic support $[31,32]$.

\subsection{Magnetic separation and reuse}

Reuse of enzymes in industrial processes is advantageous from an economic point of view. The reuse of cellulase-immobilized MNPs was investigated because the magnetic properties and enhanced enzyme stability and reusability were intended to facilitate multiple cycles. Fig. 5(d) shows the activity of cellulase-immobilized MNPs after multiple cycles of magnetic separation and reuse. Although the activity of the immobilized cellulase began to decrease after three cycles, more than $70 \%$ of its initial activity was retained after $10 \mathrm{cy}-$ cles. Earlier studies of cellulase immobilization on polyamidoamine-grafted silica reported that $75 \%$ activity was retained after three cycles. In another study, $41 \%$ activity was retained after six cycles when the enzyme was attached using adsorption, and $67 \%$ when the enzyme was covalently crosslinked [33]. Some reports have indicated that the gradual loss of enzyme activity after only a few cycles occurs because of factors such as product inhibition, structural modification of the enzyme, protein denaturation, and inactivation of the enzyme [28]. Because the nanoparticle was magnetic in nature, it facilitated easy separation and recovery of the immobilized enzyme from the reaction mixture, supporting its reusability.

\section{Conclusions}

The immobilization of cellulase onto a functionalized nanoparticle was achieved, and the optimal immobilization conditions using response surface methodology were evaluated. The binding efficiency onto MNPs was about 92\%. The binding of cellulase onto MNPs was supported by FTIR spectroscopy. The characterization of nanoparticles was determined by XRD and SEM methods. The activity of the enzyme was further confirmed by the CMC activity method. This study showed that the 
immobilization of cellulase enzyme via glutaraldehyde activation onto magnetic nanoparticles improved stability over free enzyme, particularly at higher $\mathrm{pH}$ values.

\section{References}

[1] M. Vellard, Curr. Opin. Biotechnol., 2003, 14, 444-450.

[2] C. Zhang, S. K. Kim, Adv. Food Nutr. Res., 2012, 65, 423-435.

[3] V. Bulmus, K. Kesenci, E. Piskin, React. Funct. Polym., 1998, 38, $1-9$.

[4] L. Cao, L. van Langen, R. A. Sheldon, Curr. Opin. Biotechnol., 2003, 14, 387-394.

[5] W. Tischer, F. Wedekind, Top. Curr. Chem., 1999, 200, 95-126.

[6] U. T. Bornscheuer, Angew. Chem. Int. Ed., 2003, 42, 3336-3337.

[7] B. C. Kim, S. Nair, J. Kim, J. H. Kwak, J. W. Grate, S. H. Kim, M. B. Gu, Nanotechnolgy, 2005, 16, S382-S388.

[8] H. F. Jia, G. Y. Zhu, B. Vugrinovich, W. Kataphinan, D. H. Reneker, P. Wang, Biotechnol. Prog., 2002, 18, 1027-1032.

[9] H. F. Jia, G. Y. Zhu, P. Wang, Biotechnol. Bioeng., 2003, 84, 406-414.

[10] M. B. F. Martins, S. I. D. Simoes, M. E. M. Cruz, R, J. Mater. Sci. Mater. Med., 1996, 7, 413-414.

[11] M. H. Liao, D. H. Chen, Biotechnol. Lett., 2001, 23, 1723-1727.

[12] S. H. Huang, M. H. Liao, D. H. Chen, Biotechnol. Prog., 2003, 19, 1095-1100.

[13] M. Koneracka, P. Kopcansky, M. Antalik, M. Timko, C. N. Ramchand, D. Lobo, R. V. Mehta, R. V. Upadhyay, J. Magn. Magn. Mater., 1999,
201, 427-430.

[14] A. Kondo, H. Fukuda, J. Ferment. Bioeng., 1997, 84, 337-341.

[15] C. M. Niemeyer, Angew. Chem. Int. Ed., 2001, 40, 4128-4158.

[16] A. Dyal, K. Loos, M. Noto, S. W. Chang, C. Spagnoli, K. V. P. M. Shafi, A. Ulman, M. Cowman, R. A. Gross, J. Am. Chem. Soc., 2003, 125, 1684-1685.

[17] S. Laurent, D. Forge, M. Port, A. Roch, C. Robic, L. V. Elst, R. N. Muller, Chem. Rev., 2008, 108, 2064-2110.

[18] C. R. Lin, Y. M. Chu, S. C. Wang, Mater. Lett., 2006, 60, 447-450.

[19] B. Z. Zheng, M. H. Zhang, D. Xiao, Y. Jin, M. M. F. Choi, Inorg. Mater., 2010, 46, 1106-1111.

[20] A. Garcia III, S. Oh, C. R. Engler, Biotechnol. Bioeng., 1989, 33, 321-326.

[21] K. Selvam, M. Govarthanan, S. Kamala-Kannan, M. Govindharaju, B. Senthilkumar, T. Selvankumar, A. Sengottaiyan, RSC Adv., 2014, 4, 13045-13051.

[22] R. V. Mehta, R. V. Upadhyay, S. W. Charles, C. N. Ramchand, Biotechnol. Technol., 1997, 11, 493-496.

[23] M. L. Verma, R. Chaudhary, T. Tsuzuki, C. J. Barrow, M. Puri, Bioresource Technol., 2013, 135, 2-6.

[24] A. Kondo, T. Urabe, K. Higashitani, J. Fermant. Bioeng., 1994, 77, 700-703.

[25] O. H. Lowry, N. J. Roseborough, A. L. Farr, R. J. Rondall, J. Biol. Chem., 1951, 193, 265-275.

[26] J. N. Gao, X. Z. Ran, C. M. Shi, H. M. Cheng, T. M. Cheng, Y. P. Su, Nanoscale, 2013, 15, 7026-7033.

[27] J. S. Moon, K. K. Park, J. H. Kim, G. Seo, Appl. Catal. A, 2000, 201,

\section{Graphical Abstract}

Chin. J. Catal., 2016, 37: 1891-1898 doi: 10.1016/S1872-2067(16)62487-7

\section{Activity and stability of bacterial cellulase immobilized on magnetic nanoparticles}

Kandasamy Selvam, Muthusamy Govarthanan, Duraisamy Senbagam, Seralathan Kamala-Kannan, Balakrishnan Senthilkumar*,

Thangasamy Selvankumar*

Muthayammal College of Arts and Science, India; Mahendra Arts and Science College, India;

Muroran Institute of Technology, Japan; Bharathidasan University, India; Chonbuk National University, South Korea;

Haramaya University, Ethiopia

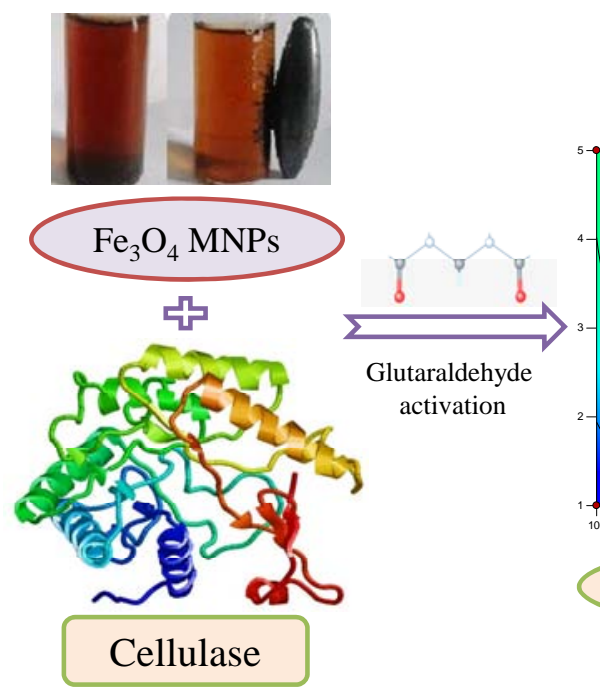

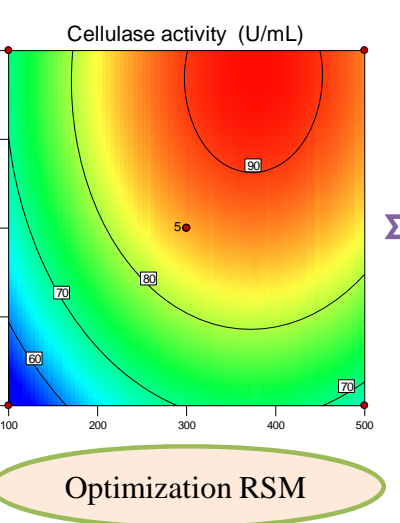

Optimization RSM

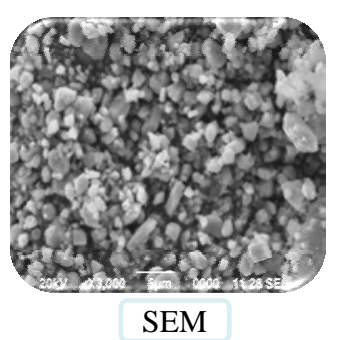

$\Rightarrow$

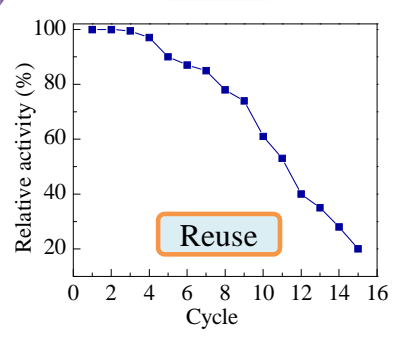

The magnetic iron oxide nanoparticles were successfully synthesized under hydrothermal conditions. Cellulase was successfully immobilized on magnetic iron oxide nanoparticles and optimal conditions using RSM. The immobilized cellulase showed enhanced activity and good reusability. 
81-89.

[28] J. Jordan, C. S. S. R. Kumar, C. Theegala, J. Mol. Catal. B, 2011, 68, 139-146.

[29] A. Ince, G. Bayramoglu, B. Karagoz, B. Altintas, N. Bicak, M. Y. Arica, Chem. Eng. J., 2012, 189-190, 404-412.

[30] T. L. Ogeda, I. B. Silva, L. C. Fidale, O. A. El Seoud, D. F. S. Petri, J.
Biotechnol., 2012, 157, 246-252.

[31] Z. X. Tang, J. Q. Qian, L. E. Shi, Mater. Lett., 2007, 61, 37-40.

[32] G. K. Kouassi, J. Irudayaraj, G. McCarty, Biomagn. Res. Technol., 2005, 3, 1 .

[33] S. M. Wang, P. Su, F. Y. Ding, Y. Yang, J. Mol. Catal. B, 2013, 89, 35-40.

\title{
磁性纳米颗粒固定化细菌纤维素酶的活性和稳定性
}

\author{
Kandasamy Selvam ${ }^{\mathrm{a}, \dagger}$, Muthusamy Govarthanan ${ }^{\mathrm{b}, \mathrm{c}, \dagger}$, Duraisamy Senbagam ${ }^{\mathrm{d}}$, \\ Seralathan Kamala-Kannan e, Balakrishnan Senthilkumar ${ }^{\text {a,f,* }}$, Thangasamy Selvankumar ${ }^{\text {b,\# }}$ \\ ${ }^{a}$ Muthayammal艺术与科学学院生物工程中心, 纳马卡尔637408, 泰米尔纳德邦, 印度 \\ ${ }^{\mathrm{b}}$ Mahendra艺术与科学学院生物工程系, 纳马卡尔637501, 泰米尔纳德邦, 印度 \\ c室兰工业大学环境工程学院应用科学系, 北海道620024, 日本 \\ d巴拉迪大学海洋生物工程系, 蒂鲁吉拉伯利620024, 泰米尔纳德邦, 印度 \\ ${ }^{\mathrm{e}}$ 全北国立大学环境和生物资源科学学院, 环境与生物科学高级研究所生物技术部, 益山570752, 韩国 \\ ${ }^{\mathrm{f}}$ Haramaya大学健康与医学科学学院医学微生物学系, 哈拉尔, 埃塞俄比亚
}

\begin{abstract}
摘要: 在氨水溶液中进行 $\mathrm{Fe}^{+2}$ 和 $\mathrm{Fe}^{+3}$ 离子共沉淀并水热处理后制得磁性纳米颗粒 $\mathrm{Fe}_{3} \mathrm{O}_{4}$, 通过戊二醛活化将纤维素酶固定于 其上. 采用基于响应面法的Box-Behnken法 (BBD)优化了制备条件, 如磁性纳米颗粒浓度、戊二醛浓度、酶浓度和交联时 间. BBD分析结果表明, 用实验数据可合理调节二次模型. 利用生成的基于统计数据的等高线评价了响应面的变化, 以理 解纳米颗粒和酶活性之间的关系. 运用扫描电镜、X 射线衍射和红外光谱表征了纳米颗粒上酶的尺寸、结构、形貌和结合 情况. 采用诸如 $\mathrm{pH}$ 值、温度、重复使用性和存储能力分析了固定化纤维素酶的活性和稳定性. 发现固定后的纤维素酶表现 出更好的稳定性和活性.
\end{abstract}

关键词: 磁性纳米颗粒; 固定化酶; 响应面法; 表征

收稿日期: 2016-05-08. 接受日期: 2016-06-14. 出版日期: 2016-11-05.

*通讯联系人. 电子信箱: nbsenthilkumar@gmail.com

\#通讯联系人. 电话: +91-9443286292, +91-9443470394; 电子信箱: t_selvankumar@yahoo.com

†共同第一作者.

本文的英文电子版由Elsevier出版社在ScienceDirect上出版(http://www.sciencedirect.com/science/journal/18722067). 